\title{
Microstructure characterization of melt spun $\mathrm{Mg}_{65} \mathrm{Cu}_{25} \mathrm{Y}_{10}$
}

\author{
M. Regev ${ }^{1}$, S. Essel ${ }^{2}$, A. Katz-Demyanetz ${ }^{2}$ \\ ${ }^{1}$ ORT Braude College of Engineering, Mechanical Engineering Department, P.O. Box 78, Karmiel, Israel \\ ${ }^{2}$ Israel Institute of Metals, Foundry Laboratory, Technion - Israel Institute of Technology, Haifa, Israel
}

Received 8 February 2016, received in revised form 29 March 2016, accepted 31 March 2016

\begin{abstract}
$\mathrm{Mg}_{65} \mathrm{Cu}_{25} \mathrm{Y}_{10}$ ribbons were produced by melt spinning. Their microstructure was investigated in its as-cast condition, after pressing under $0.5 \mathrm{GPa}$ for 5 min under different temperatures - RT, $50,100,150$, and $200^{\circ} \mathrm{C}$ - and after five-minute exposure to the above temperatures without pressing. The microstructure was characterized by means of XRD, DSC, HRSEM, and HRTEM. XRD and DSC studies showed that the as-cast material had an amorphous character and that the material crystallized during exposure to temperature with or without applying stress. HRTEM revealed that the as-cast $\mathrm{Mg}_{65} \mathrm{Cu}_{25} \mathrm{Y}_{10}$, although known to be one of the best glass formers, is nano-crystalline rather than amorphous.
\end{abstract}

K e y w ord s: microstructure, melt spinning, metallic glass, $\mathrm{Mg}_{65} \mathrm{Cu}_{25} \mathrm{Y}_{10}$

\section{Introduction}

Magnesium alloys are characterized by good physical properties: they exhibit high strength, are lightweight, and have good damping absorption and good thermal and electrical conductivity. Amorphous magnesium alloys, moreover, exhibit higher strength, hardness, and a large elastic domain in addition to having excellent corrosion resistance. Among the various existing magnesium alloys, the $\mathrm{Mg}-\mathrm{Cu}-\mathrm{Y}$ system is known to be one of the best glass formers. The $\mathrm{Mg}_{65} \mathrm{Cu}_{25} \mathrm{Y}_{10}$ was reported in early publications of Inoue et al. [1,2], who pointed at $\mathrm{Cu}$ content of 25 at.\% as optimal for high glass forming ability (GFA). In [2], Inoue and Masumoto claimed that amorphous alloys with a large temperature interval $\Delta T_{\mathrm{x}}\left(=T_{\mathrm{g}}-T_{\mathrm{x}}\right)$, where $T_{\mathrm{g}}$ is the glass transition temperature, and $T_{\mathrm{x}}$ is the onset temperature of crystallization, have high GFA. Growing interest in high glass forming abilities (GFAs) has led to the formulation of the following three empirical rules for the characteristics required of manufactured bulk metallic glass (BMG) [3]: (1) multicomponent systems consisting of more than three elements; (2) significant difference in atomic size ratios above approximately $12 \%$ among the main constituent elements; and (3) negative heats of mixing among the three main constituent elements.
Many investigations were conducted on amorphous $\mathrm{Mg}_{65} \mathrm{Cu}_{25} \mathrm{Y}_{10}$ obtained by different casting processes. Namely, pressure die casting $[1,2]$, injection into a copper mould [4-11], injection into a water-cooled $\mathrm{Cu}$ mould [12], melt spinning [13-16], rapid quenching without listing the exact process $[17,18]$, and permanent mould without stating anything about the mould [19].

The characterization techniques used in order to determine the amorphous structure of the $\mathrm{Mg}_{65} \mathrm{Cu}_{25}$ $\mathrm{Y}_{10}$ alloy included X-Ray Diffraction (XRD) [1, 4-19], Differential Scanning Calorimetry (DSC) $[1,2,4-6$, 8-16, 18, 19], and Transmission Electron Microscopy (TEM) $[1,4,6,7,11,14,16,17]$.

Some studies deal with the thermal stability of the amorphous structure and with the way the alloy crystallizes due to exposure to temperature [4, $7,11,18,19]$. Yet all researchers seem to agree that the $\mathrm{Mg}_{65} \mathrm{Cu}_{25} \mathrm{Y}_{10}$ alloy when cast at sufficiently rapid cooling rates, is fully amorphous in its as-cast condition.

Previous studies on melt spun $\mathrm{Mg}_{80} \mathrm{Cu}_{15} \mathrm{Y}_{5}$ and $\mathrm{Mg}_{80} \mathrm{Cu}_{10} \mathrm{Y}_{10}$ ribbons published by the authors [20] showed that according to XRD and DSC the material was amorphous. However, High-Resolution Transmission Electron Microscopy (HRTEM) revealed that the material was, at least partially, nano-crystalline.

*Corresponding author: tel.: +972 4 9901734; fax: +972 4 9901886; e-mail address: michaelr@braude.ac.il 
Having noticed that none of the above-mentioned references includes HRTEM of amorphous $\mathrm{Mg}_{65} \mathrm{Cu}_{25} \mathrm{Y}_{10}$ it was decided to apply HRTEM in order to investigate the amorphous character of the material, the thermal stability of the amorphous structure, and the occurrence of stress-induced crystallization. This paper focuses on HRTEM study of as-cast $\mathrm{Mg}_{65} \mathrm{Cu}_{25} \mathrm{Y}_{10}$ together with other characterization tools, namely, X-Ray Diffraction (XRD), High-Resolution Scanning Electron Microscope (HRSEM), and DSC. The above tools were also used in order to investigate the stability of the microstructure during exposure to high temperatures together with its tendency to stress-induced crystallization.

\section{Experimental procedure}

The chemical composition studied was, as mentioned above, $\mathrm{Mg}_{65} \mathrm{Cu}_{25} \mathrm{Y}_{10}$. Pure $\mathrm{Mg}$ and $\mathrm{Cu}$ metals and a Mg-40 wt.\% Y master alloy were used for the alloy preparation. Alloying was carried out in a graphite crucible under an Ar protective atmosphere. The materials blend was melted and then homogenized at $800^{\circ} \mathrm{C}$ for $1 \mathrm{~h}$ under an Ar protective atmosphere before casting. The alloy was then remelted and cast by a melt-spinning machine with a brass drum rotating at $1000 \mathrm{rpm}$. The final product was $\sim 80 \mu \mathrm{m}$ thick ribbons. These $\mathrm{Mg}_{65} \mathrm{Cu}_{25} \mathrm{Y}_{10}$ ribbons then underwent the following treatments:

1. Pressing under $0.5 \mathrm{GPa}$ for $5 \mathrm{~min}$ under different temperatures: RT, 50, 100, 150 , and $200^{\circ} \mathrm{C}$.

2. Five-minute exposure to the above temperature without pressing in order to estimate the combined effect of pressure and temperature.

XRD tests were performed using Stationary Riga$\mathrm{ku}$ Smart Lab diffractometer equipped with a $\mathrm{Cu}$ tube $\left(\lambda_{\mathrm{K} \alpha}=1.5406 \AA\right)$. The melt-spun specimen was ground to a powder having an average grain size of about $500 \mu \mathrm{m}$ prior to the XRD tests in order to eliminate any texture influence. The microstructure was studied under a Zeiss Ultra Plus HRSEM. TEM investigation was conducted using an FEI Titan 300KV HRTEM. TEM specimens were prepared as follows: film.

$-80 \mu \mathrm{m}$ thick slices were cut from the melt-spun

- The slices were ion milled using a Gatan-600 laser-terminated dual ion miller with an acceleration voltage of $5 \mathrm{kV}$ and a current of $5 \mathrm{~mA}$. The initial milling angle was $25^{\circ}$, which was then changed to $10^{\circ}$. The specimens were continually cooled with the aid of liquid nitrogen in order to avoid artifacts resulting from specimen heating.

The DSC study summarized in the current paper is based on scanning experiments. The melt-spun specimens were heated using a DSC 204F1 Phoenix

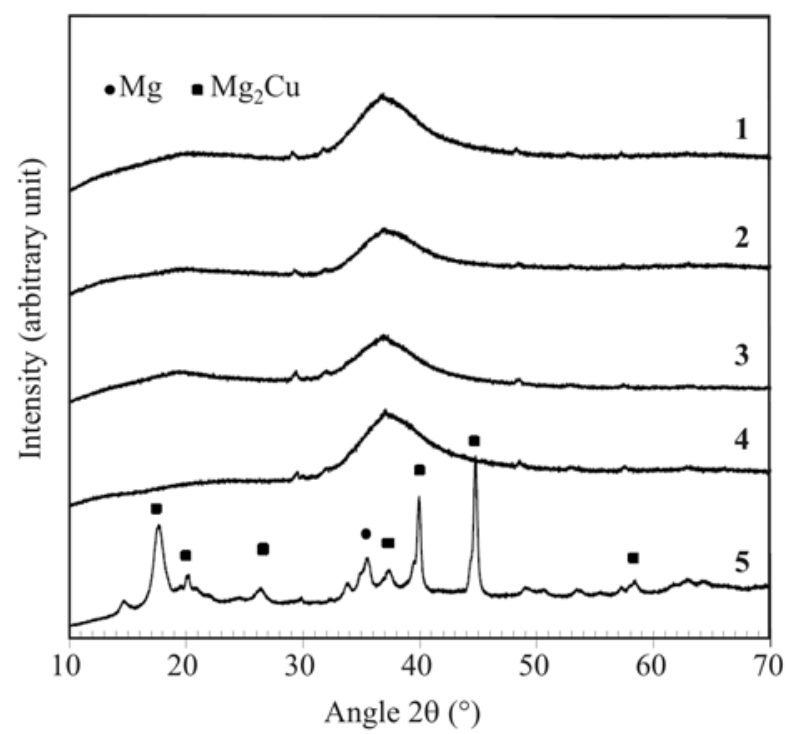

Fig. 1. XRD patterns of $\mathrm{Mg}_{65} \mathrm{Cu}_{25} \mathrm{Y}_{10}$ in its as-cast condition (1) and after a 5 -minute exposure to $50{ }^{\circ} \mathrm{C}(2), 100{ }^{\circ} \mathrm{C}$ (3), $150^{\circ} \mathrm{C}(4)$, and $200^{\circ} \mathrm{C}(5)$.

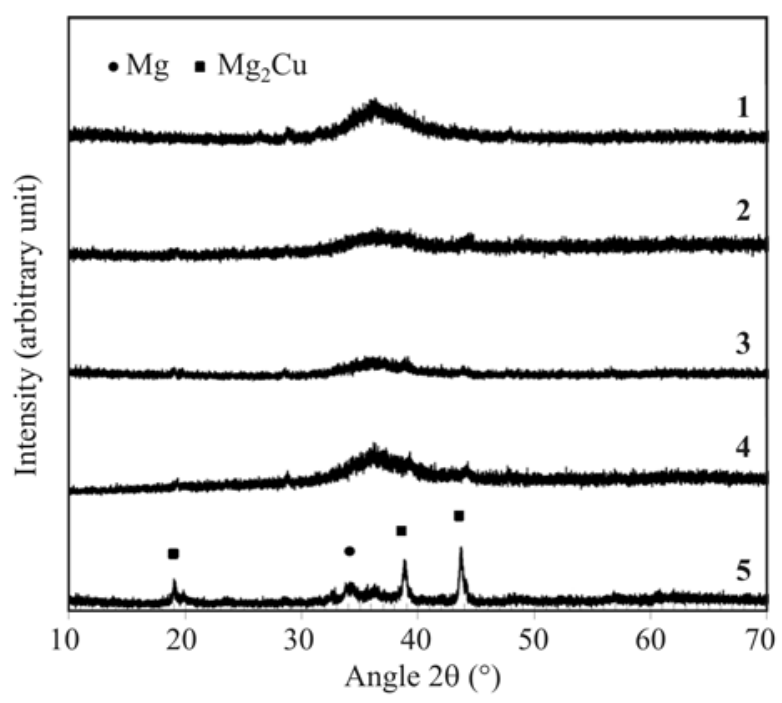

Fig. 2. XRD patterns of $\mathrm{Mg}_{65} \mathrm{Cu}_{25} \mathrm{Y}_{10}$ pressed under 0.5 $\mathrm{GPa}$ for $5 \mathrm{~min}$ at $\mathrm{RT}(1), 50^{\circ} \mathrm{C}(2), 100^{\circ} \mathrm{C}(3), 150{ }^{\circ} \mathrm{C}(4)$, and $200^{\circ} \mathrm{C}(5)$.

calorimeter at a constant rate of $10^{\circ} \mathrm{C} \mathrm{min}{ }^{-1}$ until they reached $700{ }^{\circ} \mathrm{C}$.

\section{Results}

Figure 1 shows the XRD spectra of the melt spun $\mathrm{Mg}_{65} \mathrm{Cu}_{25} \mathrm{Y}_{10}$ in its as-cast condition and after fiveminute exposure to 50,100, 150 , and $200{ }^{\circ} \mathrm{C}$, while Fig. 2 shows the XRD spectra of the specimens ex- 


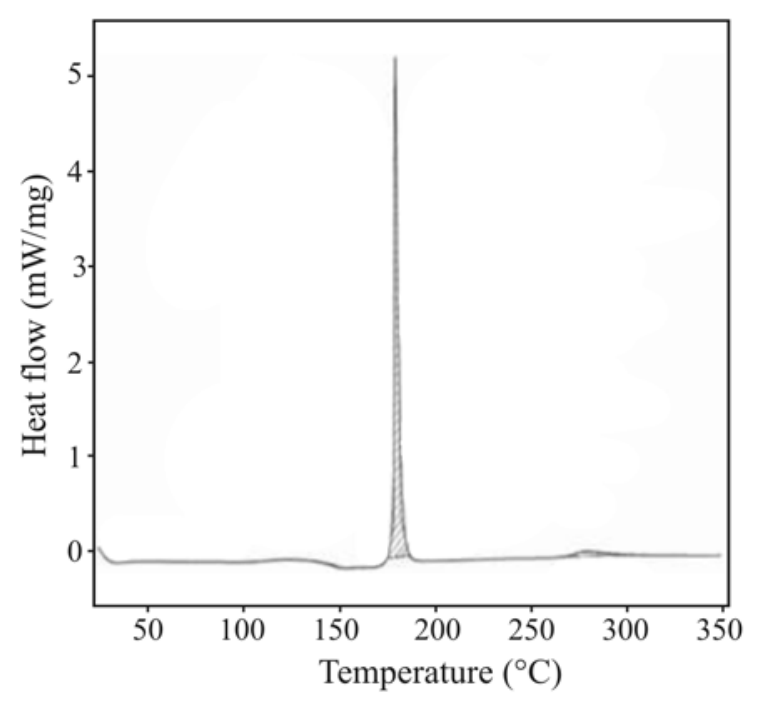

Fig. 3. A DSC curve of the as-cast $\mathrm{Mg}_{65} \mathrm{Cu}_{25} \mathrm{Y}_{10}$.

posed to the same temperatures for the same time intervals together with pressing under 0.5 GPa.

The figures show that the XRD spectrum of the as-cast material is amorphous. The material loses its amorphous character with exposure to $200^{\circ} \mathrm{C}$, where crystalline peaks of $\mathrm{Mg}$ and $\mathrm{Mg}_{2} \mathrm{Cu}$ are discernible. The small peak that appears near $2 \theta=34^{\circ}$ might be related to the $\varepsilon\left(\mathrm{Mg}_{24} \mathrm{Y}_{5}\right)$ phase, which is expected under equilibrium conditions. The spectra referring to 50,100 , and $150^{\circ} \mathrm{C}$ remained amorphous. The XRD spectra in Fig. 2 show that applying stress during exposure to different temperatures did not make any difference. Namely, the material remained amorphous under all temperatures except $200^{\circ} \mathrm{C}$.

Figure 3 shows the DSC curve of the as-cast $\mathrm{Mg}_{65} \mathrm{Cu}_{25} \mathrm{Y}_{10}$. Three peaks are discernible in this curve. The first peak, at $145^{\circ} \mathrm{C}$, corresponds to the glass transition temperature $\left(T_{\mathrm{g}}\right)$, the second one, at $180^{\circ} \mathrm{C}$, is the $\mathrm{Mg}$ crystallization peak $\left(T_{\mathrm{x}}\right)$, while the third one is also a crystallization peak, probably of the $\mathrm{Mg}_{2} \mathrm{Cu}$ phase.

An HRSEM image of the amorphous ribbons in its as-cast condition is given in Fig. 4, while Fig. 5 shows an HRSEM image of the material that had been exposed to $200^{\circ} \mathrm{C}$ for five minutes prior to its study. The figures show that the heat-treated material is composed of equiaxed grains having an average diameter of a few hundreds of microns, while no grains are discernible in the case of the as-cast material, even under higher magnification than in Fig. 4.

An HRTEM micrograph of the as-cast material and the respective FFT (Fast Fourier Transform) pattern are shown in Figs. 6a and 6b, respectively. The rectangle shown in Fig. $6 \mathrm{a}$ is the region from which the FFT was taken. Figure $6 \mathrm{a}$ shows that the material is nanocrystalline with an average grain size of a

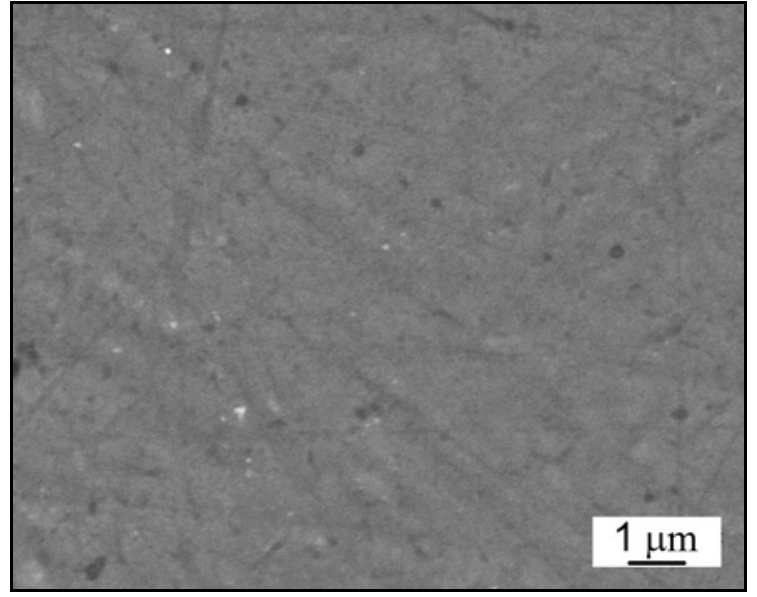

Fig. 4. HRSEM image of the as-cast $\mathrm{M}_{65} \mathrm{Cu}_{25} \mathrm{Y}_{10}$.

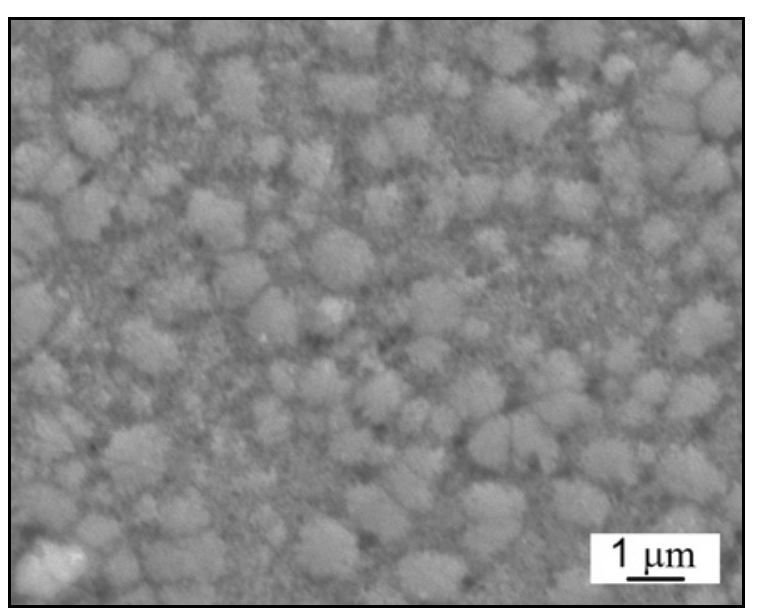

Fig. 5. HRSEM image of the $\mathrm{M}_{65} \mathrm{Cu}_{25} \mathrm{Y}_{10}$ after a 5-minute exposure to $200^{\circ} \mathrm{C}$.

few nanometres, while the diffraction pattern given in Fig. $6 \mathrm{~b}$ was taken from one of the nano-grains shown in Fig. 6a and is typical of a crystalline material. The indexed FFT refers to [0111] zone axis taken from an HCP lattice.

\section{Discussion}

As stated earlier, XRD spectra of the as-cast material and those referring to 50, 100 , and $150^{\circ} \mathrm{C}$ are amorphous, and applying stress during exposure to temperature does not seem to enhance crystallization. Contrary to the above spectra, the material lost its amorphous character during exposure to $200^{\circ} \mathrm{C}$. This change can be related to exposure to high temperature. It should be mentioned that the $\mathrm{Mg}$ and $\mathrm{Mg}_{2} \mathrm{Cu}$ peaks are slightly shifted to lower angles (higher d-spacing). This shift can be related to the existence 

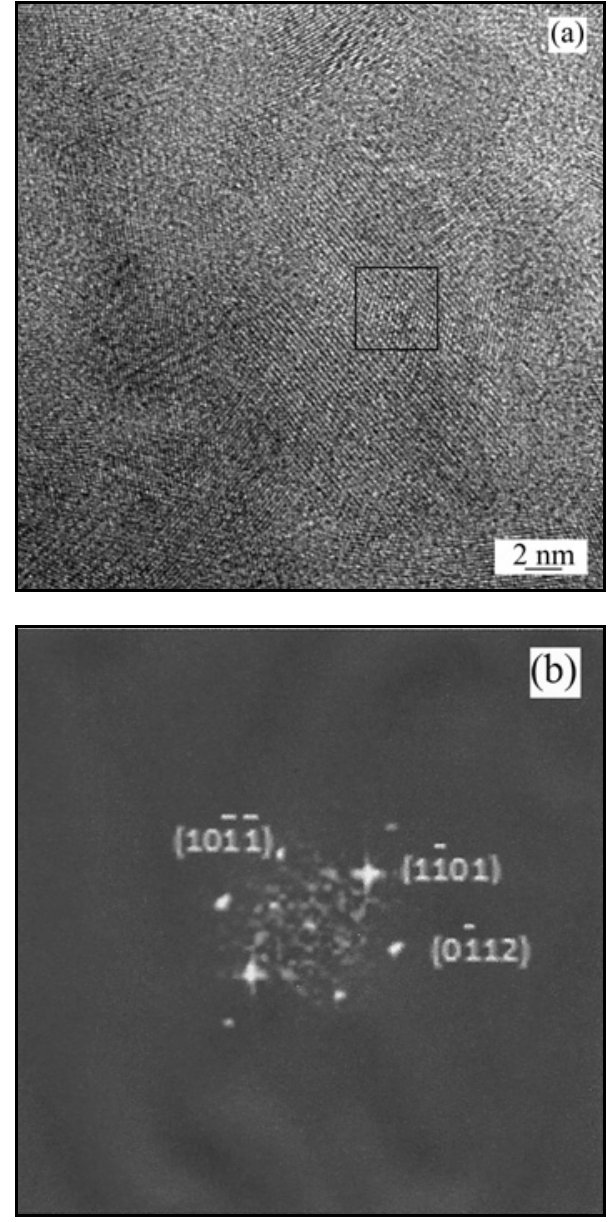

Fig. 6. (a) HRTEM image of the as-cast material; (b) an indexed FFT taken from the grain designated in (a).

of dissolved Y. The $\mathrm{Mg}-\mathrm{Cu}$ phase diagram [21] shows that both $\mathrm{Mg}$ and $\mathrm{Mg}_{2} \mathrm{Cu}$ co-exist at RT under equilibrium conditions. No peaks of $\mathrm{Mg}-\mathrm{Y}$ intermetallics were identified whatsoever. Therefore, the assumption is that due to the extremely high cooling rates the $\mathrm{Y}$ appears in a $\mathrm{Mg}$ solid solution.

According to Chen and Spaepen [22], the DSC signals of nucleation and growth of truly amorphous materials exhibit characteristic differences from the grain growth of pre-existing grains. In the case of a grain growth peak, the leading edge is steeper than the trailing edge, while in the case of nucleation and growth the opposite is true. It is difficult to determine the character of the $\mathrm{Mg}$ crystallization peak $\left(T_{\mathrm{x}}\right)$ at $180^{\circ} \mathrm{C}$, while the crystallization peak around $280^{\circ} \mathrm{C}$ seems to be a grain growth peak.

Contrary to Fig. 5, in which clear grains and grain boundaries are discernible, no grain structure can be identified in Fig. 4, in line with the XRD and DSC results. The average grain size in the case of the material exposed to $200^{\circ} \mathrm{C}$ for $5 \mathrm{~min}$ was around $1 \mu \mathrm{m}$, while no grain structure was recorded by HRSEM even un- der higher magnification than that in Fig. 4. However, the HRTEM study revealed that the material is nanocrystalline in its as-cast condition, and its grains are a few nanometres in size. Moreover, an FFT as shown in Fig. 5b provides clear evidence for the material being nano-crystalline. As stated earlier, all researchers seem to agree that the $\mathrm{Mg}_{65} \mathrm{Cu}_{25} \mathrm{Y}_{10}$ alloy, when cast at sufficiently rapid cooling rates, is fully amorphous in its as-cast condition. This means, in turn, that the current results are not in line with previous results summarized in the introduction section. However, none of the above-mentioned studies included HRTEM. The ambiguous readings of the various characterization tools can be reconciled as follows. Under the assumption that the grains are spherical with an average grain size of about $8 \mathrm{~nm}$ and that the width of the grain boundary region is about $2 \mathrm{~nm}(10-15$ times the magnesium lattice parameter), as can be seen in Fig. 5, the volume fraction of the grain boundaries turns out to be about $70 \%$. Keeping in mind that the amorphous XRD pattern obtained in the case of the as-cast melt spun specimen originates both from the contribution of the grain boundaries and from the presence of very fine crystals, the contribution of the grain boundaries, which are amorphous by definition, is responsible for the amorphous character of the XRD spectrum. In summary, according to XRD and DSC, the as-cast $\mathrm{Mg}_{65} \mathrm{Cu}_{25} \mathrm{Y}_{10}$ can be regarded as amorphous. No crystalline structure can be identified by means of HRSEM, while clear nano-grains were observed by means of HRTEM. Keeping in mind that the $\mathrm{Mg}_{65} \mathrm{Cu}_{25} \mathrm{Y}_{10}$ is known to be one of the best glass formers, the general question left to be answered is whether there are "true" amorphous materials or whether crystallinity will always be revealed under the sufficiently high resolution.

\section{Conclusions}

- The microstructure of melt spun $\mathrm{Mg}_{65} \mathrm{Cu}_{25} \mathrm{Y}_{10}$ in its as-cast condition was investigated by means of XRD, DSC, HRSEM, and HRTEM. XRD study was conducted on the material after five-minute exposure to $50,100,150$, and $200^{\circ} \mathrm{C}$ as well as on specimens exposed to the same temperatures for the same time intervals together with pressing under $0.5 \mathrm{GPa}$.

- The XRD pattern of the as-cast material was found to be amorphous, while the material lost its amorphous character with exposure to $200^{\circ} \mathrm{C}$. The spectra referring to 50,100 , and $150^{\circ} \mathrm{C}$ remained amorphous. Applying stress during exposure did not seem to expedite crystallization.

- Glass transition peak and crystallization peak of Mg were identified during DSC study, while another crystallization peak recorded probably refers to the $\mathrm{Mg}_{2} \mathrm{Cu}$ phase. 
- HRSEM revealed grain structure in the case of exposure to $200^{\circ} \mathrm{C}$. The material was found to be composed of equiaxed grains having an average diameter of a few hundreds of microns.

- HRTEM study showed that the melt spun $\mathrm{Mg}_{65} \mathrm{Cu}_{25} \mathrm{Y}_{10}$ in its as-cast state is nanocrystalline with an average grain size of about $8 \mathrm{~nm}$.

- The amorphous character of the XRD and DSC spectra is proposed to be due to the contribution of the grain boundaries, the volume fraction of which can be estimated to be about $70 \%$.

\section{References}

[1] Inoue, A., Nakamura, T., Nishiyama, N.: Mater. Trans. JIM, 33, 1992, p. 937. doi:10.2320/matertrans1989.33.937

[2] Inoue, A., Masumoto, T.: Mater. Sci. Eng. A, 173, 1993, p. 1. doi:10.1016/0921-5093(93)90175-e

[3] Inoue, A.: Acta Mater., 48, 2000, p. 279. doi:10.1016/s1359-6454(99)00300-6

[4] Gun, B., Laws, K. J., Ferry, M.: J. Non-Cryst. Solids, 352,2006 , p. 3887. doi:10.1016/j.jnoncrysol.2006.06.024

[5] Park, E. S., Kang, H. G., Kim, W. T., Kim, D. H.: J. Non-Cryst. Solids, 279, 2001, p. 154. doi:10.1016/s0022-3093(00)00412-9

[6] Gun, B., Laws, K. J., Ferry, M.: Mater. Sci. Eng. A, 471, 2007, p. 130. doi:10.1016/j.msea.2007.02.121

[7] Huang, K., Chen, G., Zhao, Y., Wang, G., Shao, Y.: Trans. Nonferrous Met. Soc. China, 22, 2012, p. 831. doi:10.1016/s1003-6326(11)61252-1

[8] Gun, B., Laws, K. J., Ferry, M.: J. Alloys Comp., 496, 2010, p. 582. doi:10.1016/j.jallcom.2010.02.116

[9] Men, H., Hu, Z. Q., Xu, J.: Scripta Mater., 46, 2002, p. 699. doi:10.1016/s1359-6462(02)00055-6
[10] Gun, B., Laws, K. J., Ferry, M.: J. Non-Cryst. Solids, 352, 2006, p. 3896. doi:10.1016/j.jnoncrysol.2006.06.023

[11] Zhang, J., Zhang, H. F., Quan, M. X., Hu, Z. Q.: Scripta Mater., 49, 2003, p. 485. doi:10.1016/s1359-6462(03)00368-3

[12] Li, Z. G., Hui, X., Zhang, C. M., Wang, M. L., Chen, G. L.: Mater. Lett., 61, 2007, p. 5018. doi:10.1016/i.matlet.2007.03.102

[13] Satta, M., Palumbo, M., Rizzi, P., Baricco, M.: Adv. Eng. Mater., 9, 2007, p. 475. doi:10.1002/adem.200700040

[14] Gebert, A., Khorkounov, B., Wolff, U., Mickel, Ch., Uhlemann, M., Schultz, L.: J. Alloys Comp., 419, 2006, p. 319. doi:10.1016/j.jallcom.2005.10.008

[15] Hung, T. H., Chang, Y. C., Wang, Y. N., Tang, C. W., Kuo, J. N., Chen, H. M., Tsai, Y. L., Huang, J. C., Jang, J. S. C., Liu, C. T.: Mater. Trans. JIM, 48, 2007, p. 1621. doi:10.2320/matertrans.mj200724

[16] Savyak, M. P., Gebert, A., Uhlemann, M.: Powder Metall. Met. Ceram., 43, 2004, p. 513. doi:10.1007/s11106-004-0013-y

[17] Du, C., Qi, H., Yan, B., Guan, L.: In: Proceedings of 3rd International Nanoelectronics Conference "INEC 2010". Ed.: Chu, P. K. Hong Kong, IEEE 2010, p. 890. doi:10.1109/inec.2010.5425144

[18] Savyak, M. P.: Powder Metall. Met. Ceram., 45, 2006, p. 196. doi:10.1007/s11106-006-0063-4

[19] Chen, G., Ferry, M.: J. Mater. Sci., 42, 2007, p. 646. doi:10.1007/s10853-006-1140-2

[20] Regev, M., Rosenson, H., Koren, Z., Katz-Demyanetz, A.: J. Mater Sci., 45, 2010, p. 6365. doi:10.1007/s10853-010-4623-0

[21] Baker, H. (Ed.): ASM Handbook. Alloy Phase Diagrams. Vol. 3. Materials Park, ASM International 1992.

[22] Chen, L. C., Spaepen, F.: J. Appl. Phys., 69, 1991, p. 679. doi:10.1063/1.347349 